\title{
Disseminated Tuberculosis Revealed by Tonsillar Location
}

\author{
A Chaouki*, N Zouhai, A Mkhatri, R Abada, S Rouadi, M Roubal and M Mahtar \\ Department of ENT, North Africa
}

Submission: November 16, 2018; Published: November 29, 2018

*Corresponding author: A Chaouki, Department of ENT, North Africa

\section{Abstract}

Tuberculosis ( $\mathrm{Tb}$ ) has been called the great simulator, its caused by Mycobacterium tuberculosis in most of the cases. Tb is an endemic illness in Morocco. We report a rare cause of tonsillar asymetry, Histopathological and bacteriological examinations established the diagnosis of tonsillar tuberculosis associated with a pulmonary and lymph node localizations.

Keywords: Tuberculosis;Tonsillar asymmetry; Necrotic tonsils.

\section{Introduction}

Tuberculosis causes significant morbidity in developing countries, but it is noted a resurgence in developed countries particularly because of HIV infection. tonsillar location is deemed rare, outpost away by the Laryngeal and cervical lymph node location. We report a case of tonsillar tuberculosis associated with cervical lymph node and active pulmonary tuberculosis. Our goal is to highlight the sociological character.

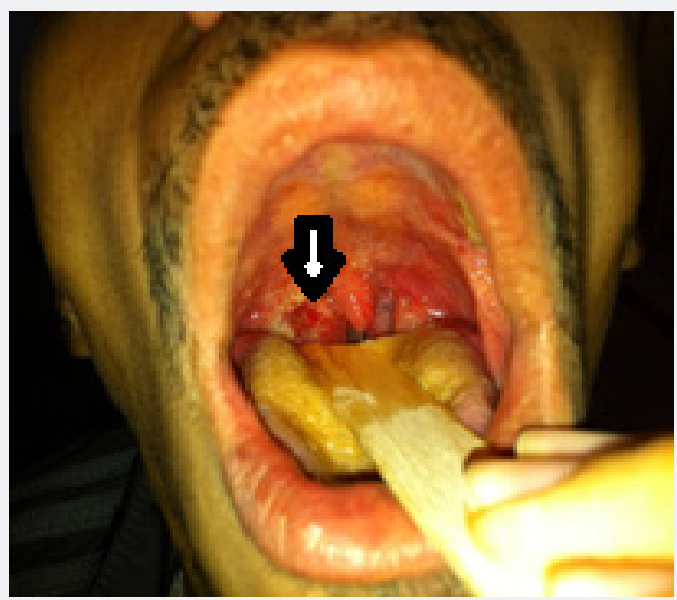

Figure 1: Inflammatory palatine tonsils with necrotic ulceration.

Case Report: Young man aged 23 was referred to the emergency of otolaryngology- head and neck surgery department ,the patient referred that 3 weeks ago, he began to notice a with sore throat associated with a productive cough, fever and poor general condition. Treatment was started with antibiotics and anti-inflammatory without significant improvement. Physical examination had revealed on the right side, an inflammatory palatine tonsils with necrotic ulceration, not bleeding (Figure 1). Nose and ears examinations were unremarkable. On examination of the neck, hard and painless right cervical lymphadenopathies were noticed, approximately measuring 2 to $5 \mathrm{~cm}$ in diameter (Figure 2). Laboratory tests revealed a leukocytosis with anemia hypochromic microcytic. A chest X-ray showed heterogeneous diffuse nodular images, interesting both lungs fields, predominantly at the right apex (Figure 3).
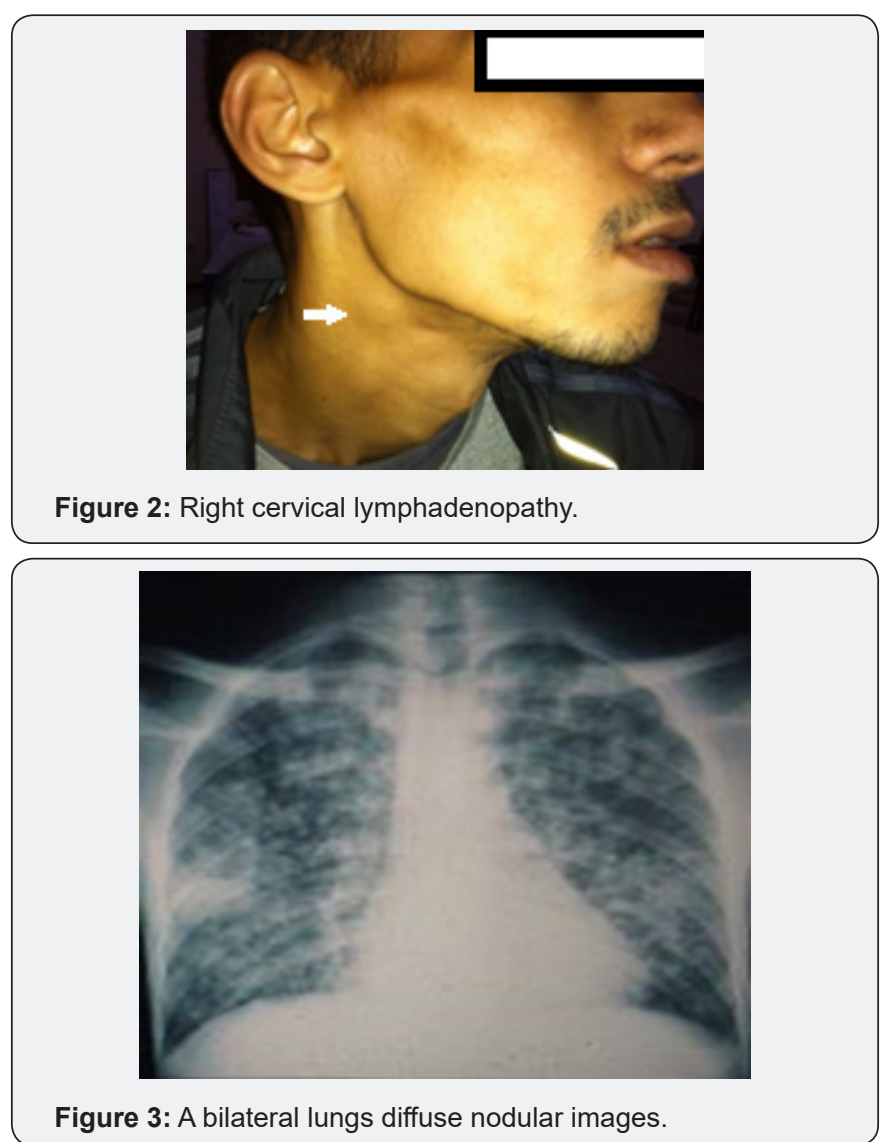
A tonsillar biopsy was performed for obtaining a histopathologic study. The postoperative study reported epithelioid cells, granulomas, multinucleated giant cells, plasmatic cells, and areas of necrosis. The removal of bronchial sputum is positive with the identification of acid-alcohol resistant bacilli. HIV serology was performed returned negative. The diagnosis was disseminated tuberculosis with lung, lymph node and tonsil localizations. TB multidrug combination ethambutol, rifampicin, isoniazid, and pyrazinamide were established for two months, followed by isoniazid and ethambuthol for six months. The outcome was favorable with no symptoms, improved nutrition and recovery of general condition after three weeks and a disappearance of lymphadenopathy after two months of treatment.

\section{Discussion}

Tb infection is usually asymptomatic due to rapidly developed immunity. Furthermore, there is a healing process which usually leaves no residual lesion. Approximately 95\% of infected patients enter into a quiescent or latent phase. Further on, the patient is at constant risk of reactivation, especially patients with a compromised immune system, including patients with diabetes mellitus, patients undergoing transplantation protocols, and HIV infected patients, among others [1,2]. In $5 \%$ of the cases, the initial infection progresses to pulmonary $\mathrm{Tb}$ directly. Other patients progress to other types of $\mathrm{Tb}$ outside the lungs. The dissemination of the bacilli is made through the lymphatic or circulating systems [3]. After laryngeal location, tuberculous otitis media is the most frequent form of $\mathrm{Tb}$ in the head and neck. Tuberculosis of the middle ear should be suspected in cases of chronic otitis media refractory to conventional treatment [4]. Tb of the oral cavity and pharynx is rare. Most references in the literature are case reports. The most reported locations are: tongue, gum, and palate. As with laryngeal forms, pulmonary lesions are frequently reported. In our patient, tonsil involvement was associated with lungs and lymphadenopathy involvement. In a review 42 cases, Mignona et al. reported a third of their cases as primary forms. The oral mucosa is relatively resistant to bacilli invasion and only occurs in $0.05-0.1 \%$ of the cases of Tb. A disruption of local mucosa is usually necessary for the invasion to take place $[1,5]$.

The upper respiratory tract is generally resistant to tuberculosis and saliva is thought to have an inhibitory effect on tubercle bacilli [6]. Brennan and Rauch have attributed this to the cleansing action of saliva. The presence of saprohytes, the antagonism of the striated musculature to bacterial invasions and thickness of the protective epithelial covering are also involved $[7,8]$. Tuberculosis of a tonsil can result from infection caused by contact with a material containing tubercle bacilli. This route of infection was important when the incidence of bovine tuberculosis was high and milk was not pasteurized [9]. Tonsillar TB commonly presents with sore throat and cervical lymphadenopathy [10]. This presentation as well as abnormal tonsillar finding, make it difficult to differentiate tonsillar tuberculosis from a malignant tumor. Diagnosis of tonsillar tuberculosis is based on histopathological findings and the identification of tubercle bacilli [11- 13]. In our patient the histopathological study and the identification of tubercle bacilli confirmed the diagnosis. Treatment is in the form of anti-tuberculosis therapy. Differential diagnosis of oral and pharyngeal tuberculosis includes traumatic ulcers, aphthous ulcers, hematological disorders, actinomycosis, syphilis, midline granuloma, Wegner's disease and malignancy [11-15].

\section{References}

1. KR Cleary, JG Batsakis (1995) Mycobacterial disease of the head and neck: Current perspective. Ann Otol Rhinol Laryngol 104(10): 830833.

2. CT Derk, RJ DeHoratius (2003) Tuberculous tonsillitis in a patient receiving etanercept treatment, Ann Rheumatic Dis 62(4): 372.

3. WHO (1991) Division of Communicable Diseases, Tuberculosis Unit, Guidelines for tuberculosis treatment in adults and children in National Tuberculosis Programmes.

4. BP Vareldzis, J Grosset, I De Kantor, J Crofton, A Laszlo, et al. (1994) Drug-resistant tuberculosis: laboratory issues. Tuber Lung Dis 75: 1-7.

5. CR Olvera, GLE Perez, CJ Villalba (1999) Tuberculosis multirresistente en Me'xico 1994-1997, Int J Tuberc Lung Dis 9: 119-120.

6. Verma A, Mann SBS, Radotra B (1989) Primary tuberculosis of the tongue. Ear Nose Throat J 68: 719-720.

7. Brennan TF, Vrabec DP (1987) Tuberculosis of oral mucosa. Ann Otol Rhinol Laryngol 79: 601-605.

8. Rauch DM, Freidman E (1978) Systemic tuberculosis initially seen as an oral ulceration: report of case. J Oral Surg 36: 387-9.

9. Speert DP (1992) Tuberculosis. In: Krugman S, Katz SL, Gershon AA, Wilfert CM, editors. In infectious Diseases of Children, 9 th ed. St Louis: Mosby-Year Book 551-72.

10. Srirompotong S, Yimtae K (2002) Clinical aspects of tonsillar tuberculosis Southeast. Asian J Trop Med Public Health 33(1): 147150 .

11. Chumakov Fl, Gerasimenko NV(2000) Isolated tuberculosis of pharyngeal and palatine tonsil. Vestn Otonnolanngol 2: 58.

12. Hajioff D, Snow Mil, Thaker H, Wilson JA (1999) Primary tuberculosis of the posterior oropharyngeal wall. J Laryngol Otol 113(11): 10291030.

13. Gupta KB, Tandon S, Jaswal TS, Singh S(2001) Tuberculosis of tonsil with unusual presentation. Ind J Tub 48: 223-224.

14. Nagar RC, Joshi CP, Kanwar DL(1985) Tuberculosis of oral cavity. Indian J Tub 32: 158-159.

15. Surya Kant, Sanjay Kumar Verma, Sanjay (2008) isolated tonsil tuberculosis. Lung India 25(4): 163-164. 
(C) (i) Commons Attribution 4.0 License

BY DOI: 10.19080/GJO.2018.18.555988
Your next submission with Juniper Publishers will reach you the below assets

- Quality Editorial service

- Swift Peer Review

- Reprints availability

- E-prints Service

- Manuscript Podcast for convenient understanding

- Global attainment for your research

- Manuscript accessibility in different formats

( Pdf, E-pub, Full Text, Audio)

- Unceasing customer service

Track the below URL for one-step submission https://juniperpublishers.com/online-submission.php 